\title{
The Influence of Heavy Metal lons on the Viability and Metabolic Enzyme Activity of the Marbled Crayfish Procambarus virginalis (Lyko, 2017)
}

\author{
Oleh Marenkov ${ }^{1^{*}}$, Mykola Prychepa $^{2}$, Julia Kovalchuk ${ }^{1}$
}

${ }^{1}$ Oles Honchar Dnipro National University, Research Institute of Biology, Research Laboratory of Hydrobiology, Ichthyology and Radiobiology, P.M.B. 49050, Dnipro, Ukraine

${ }^{2}$ Institute of Hydrobiology of NAS of Ukraine, P.M.B. 04210, Kyiv, Ukraine

"gidrobions@gmail.com

Keywords: manganese, nickel, lead, crustaceans, Procambarus virginalis, succinate dehydrogenase, lactate dehydrogenase, alkaline phosphatase.

\begin{abstract}
The article shows the results of studies on the influence of heavy metal ions (manganese, nickel, lead) on the viability and metabolic enzyme activity of marbled crayfish Procambarus virginalis (Lyko, 2017) (Decapoda). Due to the fact that marbled crayfish got into the reservoirs of the Dnipropetrovsk region in 2015, it was necessary to study the possibilities of its adaptation to environmental factors of reservoirs for further prediction of its distribution or even acclimatization under conditions of toxicological contamination of the ponds of the steppe Prydniprovya. In the experiment with marbled crayfish, chronic effects of various concentrations of heavy metal ions on the physiological state and enzyme activity were investigated. The obtained results showed that among the investigated heavy metals nickel ions influenced the weight indexes and mortality of crustaceans the most negatively. According to the results of the research, significant changes were noted in the individual biochemical parameters of marbled crayfish under the influence of manganese, lead and nickel ions. The most significant changes in the activity of lactate dehydrogenase were detected in muscle tissues affected by manganese and nickel ions. A significant decrease in the activity of succinate dehydrogenase in muscle of marbled crayfish was determined after the action of heavy metal ions. Investigation of changes in the activity of alkaline phosphatase under the influence of the ions of manganese, lead and nickel has its own characteristics, which indicates certain violations in the tissues of cell membranes. Changes in the activity of enzymes were also reflected in the overall protein content. In conclusion, changes in these parameters may indicate a rapid biochemical response of crustaceans to the toxic effects of heavy metals.
\end{abstract}

\section{Introduction}

The use of a number of physiological and biochemical indicators allows assessing the featues of the course of metabolic processes in hydrobionts from torn ranges in the process of their adaptation to new conditions of existence [1]. The disturbance of vital functions of hydrobionts living in changed conditions is precisely at the biochemical level [2]. These changes reflect the influence of environmental factors and allow us to assess and diagnose ecosystem condition [3]. The physiological and biochemical state of hydrobionts on the basis of determination of enzymatic activity allows us to determine the presence of stress and adverse environmental conditions [4-6].

In these studies it is necessary to identify the most informative biochemical indicators, which can be used to assess the physiological state of hydrobionts, which are exposed to anthropogenic factors. By assessing their condition, we can also predict changes in hydrobiocenoses $[1,3,5]$.

It is known that the adaptation of hydrobionts to specific environmental conditions occurs both in their morphometric and morphophysiological characteristics, and at the physiological and biochemical levels $[3,5,6]$. Therefore, the study of these characteristics on the example of various hydrobionts makes it possible to assess the ecological conditions of a separate ecosystem. 
The study of adaptation possibilities of new species of hydrobionts, which are first introduced to reservoirs with a sustainable ecological regime and the formed toxicological background, is of particular interest. In this case, new species can either perish without withstanding the pressure of anthropogenic factors, or vice versa, adapt to new conditions. At the same time, the adaptation process, which takes place at the biochemical and cellular levels, creates the preconditions for the survival of the population of the invasive species [1].

Due to the fact that marbled crayfish has entered waters of Dnipropetrovsk [7], the necessity to study the possibility of its adaptation to environmental conditions of water bodies with an aim to predict its spread, or even acclimatization under conditions of toxicological water pollution of steppe Prydniprovya $[1,3,8,9]$.

Marbled crayfish Procambarus virginalis (Lyko, 2017) (earlier known as parthenogenetic form of Procambarus fallax $f$. virginalis Martin et al., 2010) (Decapoda, Cambaridae) are parthenogenetic crustaceans, found in 1990 in the German reservoirs [10-13]. Marbled crayfish was previously described as a subspecies of the American species Procambarus fallax (Hagen, 1870), the natural area of which covers the waters of Georgia and Florida (USA) [14, 15]. These crustaceans came to Europe as an ornamental species and were released to the waters of Germany $[16,17]$. As an alien species, marbled crayfish is observed in the waters of the Netherlands, Italy [18], Slovakia [19], Sweden [20], Czech Republic [21], Ukraine [7] and Japan [22]. Marble crayfish is typical invasive hydrobiont [23]. Populations of marbled crayfish consist of triploid females, and their reproduction is parthenogenetic [24-27]. All individuals are females, which are genetically identical to the parent [27]. Thus, marbled crayfish can be used as indicative model objects in biological research [12, 28, 29].

In this regard, current research is aimed to determine the influence of heavy metal ions on the physiological state and histostructure of tissues and organs of marbled crayfish. The working hypothesis of the study was based on the determining the reaction of the organism of marble crayfish to the influence of the simulated concentrations of nickel, manganese and lead ions under controlled conditions: the influence of heavy metals on the weight indices of crustaceans and their enzymatic activity.

\section{Materials and Methods}

The muscle tissue of 44 marbled crayfish P. virginalis (Lyko, 2017) was used in the study to investigate the influence of heavy metal ions on viability and metabolic enzyme activity. Crayfish were divided into 4 groups $(\mathrm{n}=15)$. The first group was a control group; the second one was the group with $\mathrm{Ni}\left(\mathrm{NO}_{3}\right)_{2} \times 6 \mathrm{H}_{2} \mathrm{O}$, (Sigma, USA); the third one was the group with $\mathrm{Pb}\left(\mathrm{NO}^{3}\right)_{2}$, (Sigma, USA); The fourth group was the one with $\mathrm{MnSo}_{4} \times 5 \mathrm{H}_{2} \mathrm{O}$ (Sigma, USA). During the experiment, there was mortality of individuals in aquariums. At the end of the study, 14 marbled crayfish were registered in the control group, 11 in the group with the lead ions, 6 in the group with the nickel and 13 in the group with the manganese. Water in aquariums was completely changed twice a week and toxicants were added at the rate of concentrations of metal ions: $\mathrm{Ni}^{2+}-0.04 \mathrm{mg} / 1$ (4 MAC), $\mathrm{Pb}^{2+}-0.15 \mathrm{mg} / \mathrm{l}$ (1.5 MAC), $\mathrm{Mn}^{2+}-0.02 \mathrm{mg} / \mathrm{l}$ (2 MAC). Concentrations of heavy metals were determined by their content in water of Zaporizhzhya (Dnipro) reservoir as control, the main recipient reservoir for this species. The influence of heavy metal ions on the enzymatic activity of marbled crayfish of marmorkrebs was determined. The experiment was conducted in 4 aquariums with capacity of $30-\mathrm{L}$. The water temperature was maintained by thermostat and was $+22^{0} \mathrm{C}$. Oxygen regime was maintained by the compressor, the oxygen content in the water of aquariums was $6-7 \mathrm{mg} / \mathrm{L}$. Special shelters made from chemically neutral material have been placed to the aquariums for avoiding the incidence of cannibalism.

During the experiment, the quality of water was determined in the following hydrochemical parameters: $\mathrm{pH}$, chloride content $\left(\mathrm{Cl}_{2}, \mathrm{mg} / \mathrm{L}\right)$, nitrates $\left(\mathrm{NO}_{3}^{-}, \mathrm{mg} / \mathrm{L}\right)$, nitrites $\left(\mathrm{NO}_{2}^{-}, \mathrm{mg} / \mathrm{L}\right)$, total hardness $\left(\mathrm{GH},{ }^{\circ} \mathrm{d}\right)$, carbonate hardness $\left(\mathrm{kH},{ }^{\circ} \mathrm{d}\right)$. Water analysis was performed using an express-test "Tetra Test 6 in 1". The hydrochemical conditions of the marbled crayfish in aquariums were identical. 
Crayfish were fed every day with the same quantity of food. Feeding of crayfish was carried out once a day, a universal bottom feed brand Nature "Somiki", the daily dose $-5 \%$ by weight of aquatic organisms (in the control and experiment fed the same amount of food). In each aquarium there were 15 parthenogenetic individuals of the marbled crayfish with the same size and age group from one female (Fig. 1). The experiment lasted 21 days and was performed according to "Provisions for the use of animals in biomedical experiments" [30]. All animals were weighed with accuracy up to $0.01 \mathrm{~g}$. Before weighing each individual was dried with filter paper until wet spots cease to appear on it.



Figure 1. Marbled crayfish at the beginning of the experiment

Biochemical parameters were determined in laboratory conditions. The activity of succinate dehydrogenase (SDH) was determined by the Vexsey method on SP-26 at a wave length of $420 \mathrm{~nm}$ [31]. The activity of lactate dehydrogenase (LDH) was determined using standard commercial sets "LDH" (Philitis-Diagnostics, Ukraine) on a spectrophotometer SP-26 at a wavelength of $340 \mathrm{~nm}$. The activity of alkaline phosphatase (ALP) was evaluated using a set of reagents called "ALP test" ("Filisit Diagnostika", Ukraine) [32]. Total protein in muscle tissues was determined on a KFK-2M concentration photocolorimeter at a wavelength of $750 \mathrm{~nm}$ by Lowry's method [33].

Statistical data processing was carried out by conventional methods using software packages for personal computers Statistica 8.0 (StatSoftInc, USA). All results are given as the mean \pm standard deviation (SD). There liability of the difference between data samples was determined using one-factor ANOVA dispersion analysis at a significance level $\mathrm{p}<0.05$. 
Region, Ukraine

\section{Results}

At the beginning of the experiment, all marbled crayfish had an average weight of individuals $0.67 \mathrm{~g}$, that is, they belonged to a same dimensional group. Compared with the beginning of the experiment, marbled crayfish in the control group, in experiment with manganese and in the experiment with lead increased their mass by $40.9-66.1 \%$. At the end of the experiment, the mass gain in the control aquarium was $0.43 \mathrm{~g}(60.6 \%)$. The largest increase in the mass of marbled crayfish was observed in a test with lead $-0.45 \mathrm{~g}(66.1 \%)$. At the end of the experiment, the statistically significant difference between the mass of crustaceans was observed between control group and experiment with nickel, the crayfish did not grow during the experiment, and even lost weight, by an average of $3.3 \%$ compared with the beginning of the experiment. Thus, among the studied heavy metals, nickel ions affected the weight indexes of crustaceans most negatively.

At the end of the experiment, the statistically significant difference between the mass of crustaceans was observed between control group and experiment with nickel, the crayfish did not grow during the experiment, and even lost weight, by an average of 3.3\% compared with the beginning of the experiment (Table 1). Thus, among the studied heavy metals, nickel ions affected the weight indexes of crustaceans most negatively.

Table 1. Weight indexes of $P$. virginalis during the experiment $(\mathrm{x} \pm \mathrm{SD})$

\begin{tabular}{|l|c|c|c|c|}
\hline Experiment conditions & Control & $\mathrm{Pb}$ & $\mathrm{Ni}$ & $\mathrm{Mn}$ \\
\hline Initial mean weight $(\mathrm{g})$ & $\begin{array}{c}0.71 \pm 0.38 \\
(\mathrm{n}=15)\end{array}$ & $\begin{array}{c}0.67 \pm 0.21 \\
(\mathrm{n}=15)\end{array}$ & $\begin{array}{c}0.65 \pm 0.25 \\
(\mathrm{n}=15)\end{array}$ & $\begin{array}{c}0.66 \pm 0.27 \\
(\mathrm{n}=15)\end{array}$ \\
\hline Final mean weight $(\mathrm{g})$ & $\begin{array}{c}1.14 \pm 0.42 \\
(\mathrm{n}=14)\end{array}$ & $\begin{array}{c}1.12 \pm 0.68 \\
(\mathrm{n}=11)\end{array}$ & $\begin{array}{c}0.63 \pm 0.15^{*} \\
(\mathrm{n}=6)\end{array}$ & $\begin{array}{c}0.94 \pm 0.38 \\
(\mathrm{n}=13)\end{array}$ \\
\hline Difference, \% & $60.56^{*}$ & $66.08^{*}$ & -3.29 & $40.99 *$ \\
\hline Crayfish survival, \% & 93.33 & 73.33 & 40.00 & 86.87 \\
\hline
\end{tabular}

Note: $*$ - Difference is significant at $\mathrm{p}<0.05$.

Heavy metals influenced not only the mass of crustaceans, but also their survival; in experimental aquariums with heavy metals we observed the death of marble crayfish. On the $21 \mathrm{st}$ day of the experiment in the lead aquarium, $26.7 \%$ of marbled crayfish were dead. In control group, one crayfish died, due to cannibalism after another molting.

In the nickel experiment, crustacean mortality was the highest and reached $60 \%$. The reaction of crayfish to poisoning with nickel ions was following: the crayfish did not consume food, became less active. Then the marbled crayfish lied on their back and did not move for a while (Fig. 2). The last stages of poisoning were accompanied by cramps of the limbs, the crayfish moved limbs convulsively, then pushed them under body, the limbs were almost impossible to be stretched out. After that, crustaceans inevitably died. 


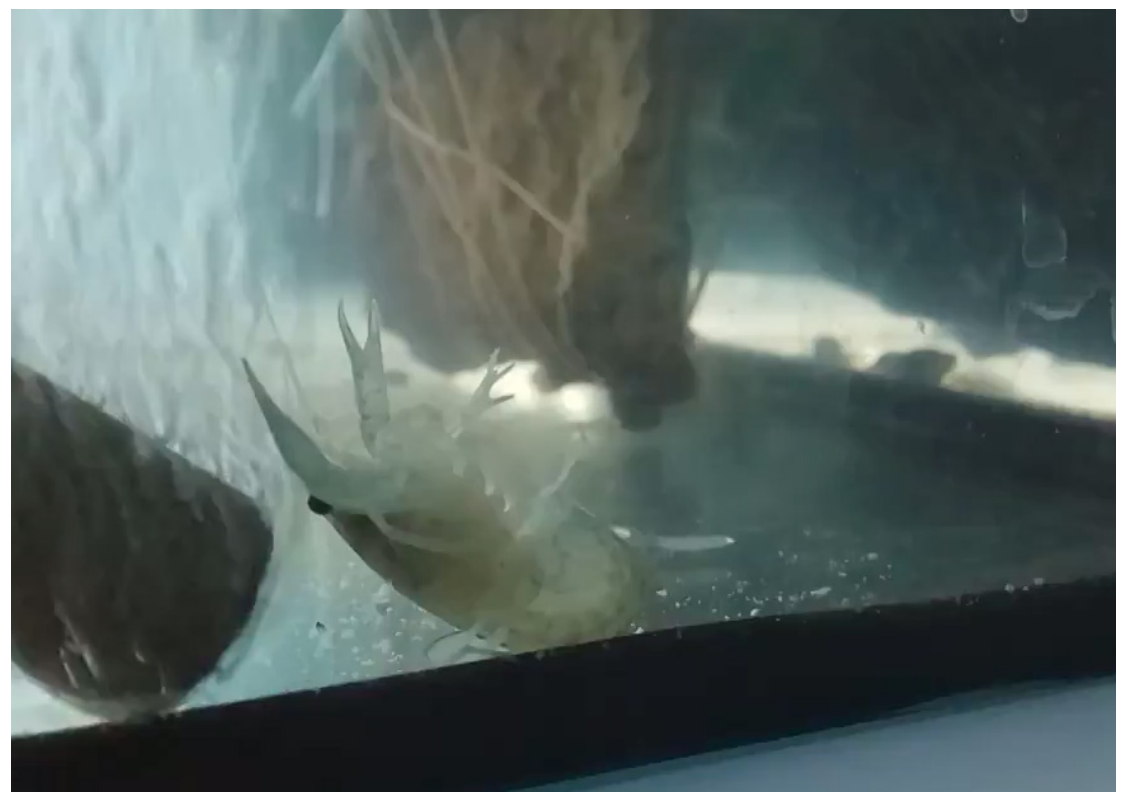

Figure 2. General appearance of marmorkrebs during the lethal action of nickel ions

Lactate dehydrogenase (LDH) is one of the enzymes that participates in the fermentation of glucose to lactic acid under anaerobic conditions (without oxygen). Due to the fact that the concentration of LDH in the blood of animals increases with deviations that are accompanied by tissues and cells damage, this enzyme is a very important diagnostic marker. In a healthy body LDH does not accumulate, but is destroyed and excreted naturally.

As an indicator of the stress, LDH activity is used to biomark the physiological state of animals, the potential pollution of the reservoirs. The use of this indicator makes it possible to assess the quality of the aquatic environment and further predict possible changes in hydrobiocenoses $[34,35]$. It is known that functional activity of LDG increases with poisoning of hydrobionts with heavy metals, phenols [36-39], organic pollutants when inhibiting tissue respiration. The growth of $\mathrm{LDH}$ activity leads to increased utilization of lactate by various tissues, with the urgent need with tissue damage by toxic, anthropogenic and abiotic factors. The rate of utilization of lactate by different tissues indicates the biochemical plasticity of hydrobionts to adverse conditions of existence. These processes contribute to the survival of resistant species of hydrobionts under toxicologically hard conditions.

According to the results of the research, it was found that the activity of lactate dehydrogenase increased by $29.6 \%$ and $32.3 \%$, during the affect of manganese and nickel on the tissues of marmorkrebs (Fig. 3). In the control group, LDH activity was $48.04 \pm 4.03 \mathrm{NADH} / \mathrm{mg}$. The influence of manganese increased the activity of lactate dehydrogenase up to $67.23 \pm$ 5.69 NADH/mg, and the influence of nickel increased it up to $69.84 \pm 2.1 \mathrm{NADH} / \mathrm{mg}$. The influence of lead also showed non-probable $(\mathrm{p}<0.05)$ changes by $15.6 \%$ in the activity of the enzyme. The activity of LDH under the influence of lead was at the level of $56.23 \pm 4.46 \mathrm{NADH} / \mathrm{mg}$. 


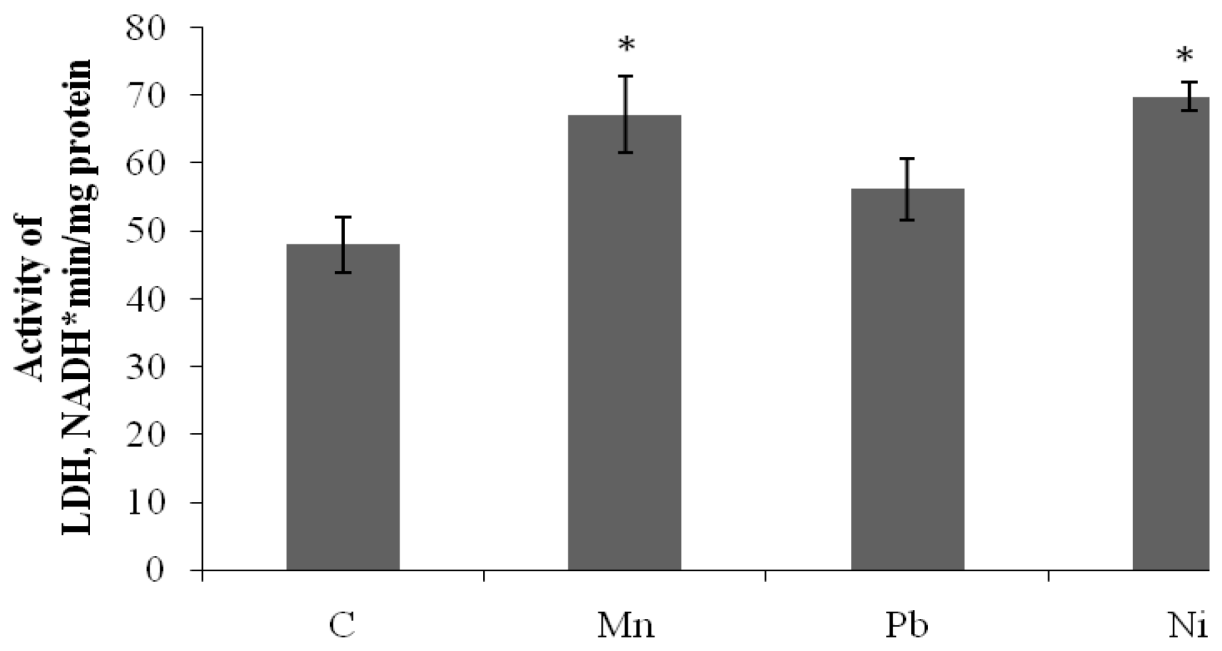

Figure 3. The activity of lactate dehydrogenase in muscles of marbled crayfish

$\mathrm{C}-$ Control group, $\mathrm{Mn}$ - group with manganese, $\mathrm{Pb}$ - group with lead, $\mathrm{Ni}$ - group with nickel. $\mathrm{n}=5$, $*-p<0.05$ comparatively to the control.

Succinate dehydrogenase is a protein complex located in the inner membrane of mitochondria and membranes of many eukaryotic organisms. At the same time, it participates in the tricarboxylic acids cycle and respiratory chain of electron transfer. Determination of the amount of succinate dehydrogenase has shown that the influence of manganese, lead and nickel decreases the activity of the enzyme by $2.5,4.3$ and 2.8 times compared with the control (Fig. 4).

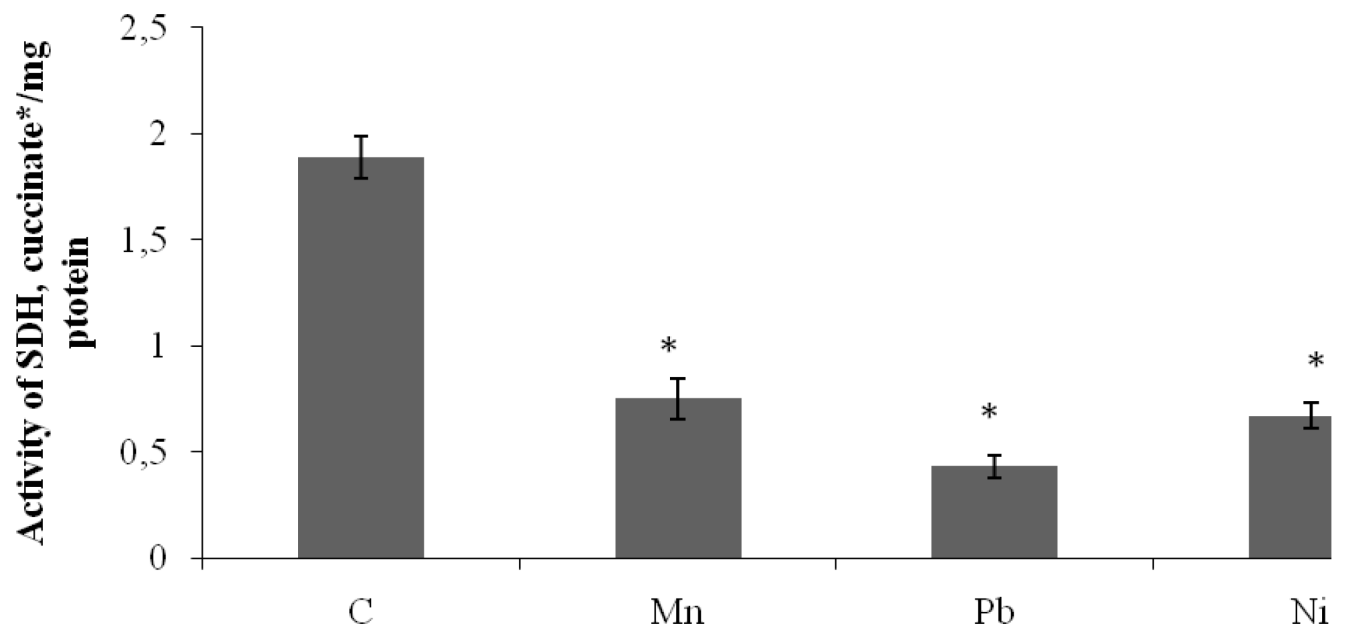

Figure 4. The activity of succinate dehydrogenase in muscles of marbled crayfish $\mathrm{C}-$ Control group, $\mathrm{Mn}$ - group with manganese, $\mathrm{Pb}$ - group with lead, $\mathrm{Ni}$ - group with nickel. $\mathrm{n}=5$, $*-p<0.05$ comparatively to the control.

The content of SDH in the control group was $1.89 \pm 0.1 \mathrm{nMol}$ succinate / $\mathrm{mg}$ protein. Under the influence of manganese there is a decrease in the activity of the enzyme to $0.75 \pm 0.095 \mathrm{nMol}$ succinate / $\mathrm{mg}$ protein, under the influence of lead it is up to $0.43 \pm 0.05 \mathrm{nMol}$ succinate / $\mathrm{mg}$ protein, and under the influence of nickel it is up to $0.67 \pm 0.06 \mathrm{nMol}$ succinate / $\mathrm{mg}$ protein.

Alkaline phosphatase is a specific enzyme that belongs to the hydrolase group. It is necessary for the body for dephosphorylation reactions, namely the removal of phosphate from organic substances, which occurs at the molecular level. It is known that an increase in the level of alkaline phosphatase indicates tissue damage, or involvement in any pathological process.

Alkaline phosphatase is one of the key enzymes of hydrobionts, which activity changes are used in biomonitoring of various ecosystems [40,41]. This enzyme is mostly involved in a number of metabolic processes, particularly, in providing molecular membrane permeability of cells, growth 
and differentiation of cells, steroidogenesis, etc. [42]. In addition, alkaline phosphatase is involved in the catabolic processes of cells and tissues of hydrobionts. It participates in the synthesis of proteins, phospholipids and glycogen $[43,44]$. Since alkaline phosphatase is sensitive to a content of toxicants in a water, it is used as a reliable indicator of toxicological stress [45-48]. The results of the study of changes in the activity of alkaline phosphatase in muscle tissue of marbled crayfish are presented in Fig. 5.

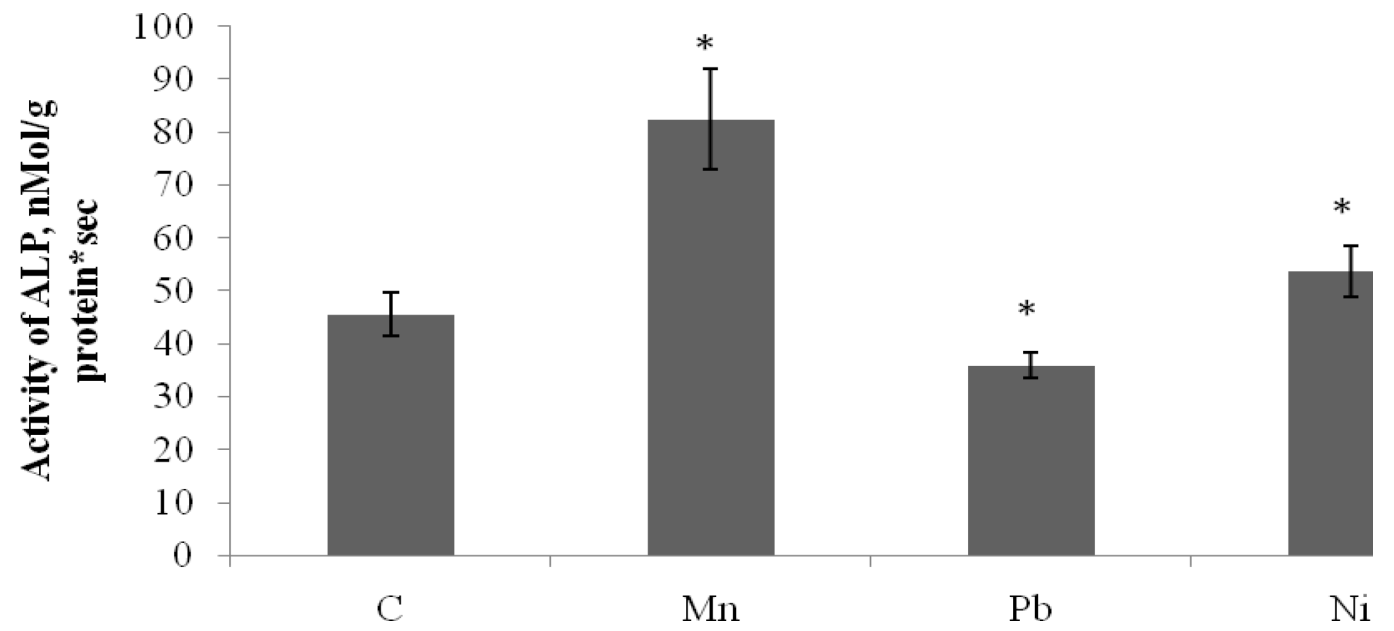

Figure 5. The activity of alkaline phosphatase in muscles of marbled crayfish $\mathrm{C}-$ Control group, $\mathrm{Mn}-$ group with manganese, $\mathrm{Pb}$ - group with lead, $\mathrm{Ni}-$ group with nickel. $\mathrm{n}=5$, * $-\mathrm{p}<0.05$ comparatively to the control.

In case of influence of the investigated concentration of lead in muscle of the crayfish revealed a decrease in the activity of the enzyme $(\mathrm{p} \geq 0.05)$ by $22.1 \%$ compared with the control group. In the control group, the activity of alkaline phosphatase in muscle tissue of marbled crayfish was $45.56 \pm 4.21 \mathrm{nMol} / \mathrm{g}$ protein $\times \mathrm{sec}$, while the influence of lead reduced the activity of the enzyme to $35.9 \pm 2.3 \mathrm{nMol} / \mathrm{g}$ protein $\times$ sec. In case of influence of nickel ions $(\mathrm{p} \leq 0.05)$ and manganese ( $\mathrm{p} \geq 0.05$ ), the activity of the investigated enzyme was increased by $14.1 \%$ and $45.8 \%$ respectively. The activity of alkaline phosphatase under the influence of nickel ions is at the level of $53.65 \pm 4.76 \mathrm{nMol} / \mathrm{g}$ protein $\times \mathrm{sec}$, while under the influence of manganese it is $82.4 \pm 9.53 \mathrm{nMol} / \mathrm{g}$ protein $\times$ sec.

The total protein content in the control group was $156.08 \pm 8.4 \mathrm{mg} / \mathrm{g}$ tissue. Under the influence of manganese, a decrease in the total protein content of $106.65 \pm 3.81 \mathrm{mg} / \mathrm{g}$ tissue was noted, with a lead it was up to $132.3 \pm 5.92 \mathrm{mg} / \mathrm{g}$ tissue, and under the nickel influence it was $88.9 \pm 4.7 \mathrm{mg} / \mathrm{g}$ tissue (Fig. 6). 


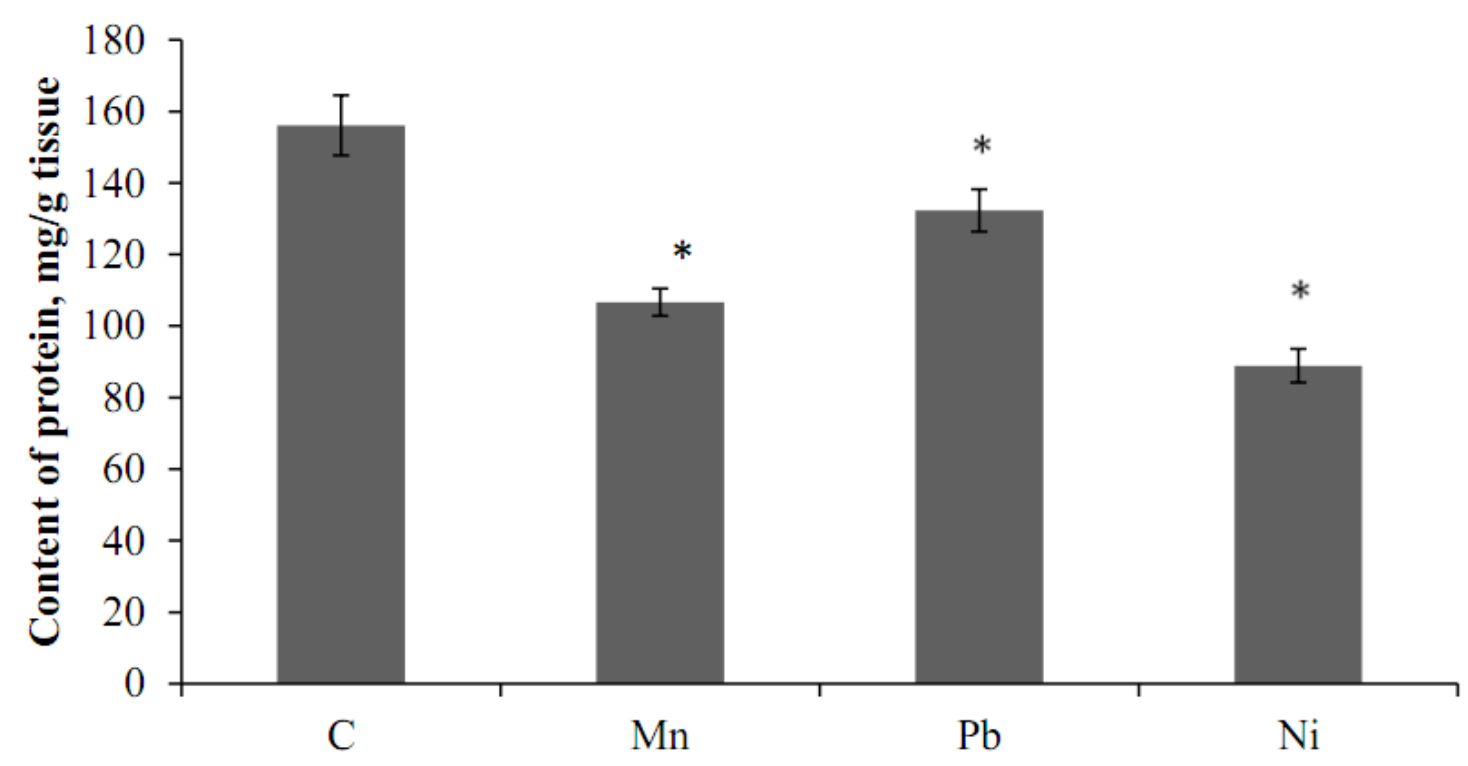

Figure 6. The total protein content

$\mathrm{C}-$ Control group, $\mathrm{Mn}$ - group with manganese, $\mathrm{Pb}$ - group with lead, $\mathrm{Ni}-$ group with nickel. $\mathrm{n}=5$, * $-\mathrm{p}<0.05$ comparatively to the control.

The long-term effects of stress factors on the organism of hydrobionts leads to the involvement of proteins for the energy needs of tissues [49]. Certain toxicants during the long-term influence on the organism of aquatic animals contribute to a decrease in the content of proteins [5053], which negatively affects the synthesis of proteins [54]. Reduced protein content in the muscles is associated with the utilization of these compounds for the process of gluconeogenesis [55, 56]. As the toxicity of the medium increases, the protein content in the tissues of hydrobionts decreases [57-60]. The protein content reflects the physiological state as a reaction to changes in the conditions of existence [61]. The dynamics of protein content in the body depends essentially on the environmental conditions of existence. The presence of toxicological effects, critical or extreme environmental conditions leads to the use of proteins as an alternative source of energy to support homeostasis in the body $[62,62]$.

\section{Discussion}

The activity of enzymes of energy exchange were considered in the study. Lactate hydrogenated is an enzyme, which is involved in the conversion of lactate to pyruvate and vice versa. The change in activity of this enzyme is widely used as an indicator of stress. In the organism of marbled crayfish, processes of glycolysis were intensified, which was caused by the effect of the investigated heavy metal ions on the organism of crayfish, in particular, they influenced the processes of energy supply [64].

In contrast, changes in the activity of succinate dehydrogenase (SDH) were detected. Oxidative enzymes, in particular SDH, play an important role in respiratory exchange [65]. SDH is one of the important oxidative enzymes in the cycle of tricarboxylic acids. According to M. Banaae and K. Fakhmadi, the effects of the influence of toxic substances of organic origin on the crayfish Astacus leptotactylus (Eschscholtz, 1823) decrease the activity of SDH [52]. Inhibition of SDH activity of marbled crayfish indicates the deterioration of the oxidative metabolic cycle and as a result of involvement of glycolysis in the energy exchange [66]. It is known that heavy metals are absorbed in the organism, which further contributes to tissue damage and causes dysfunction of specific organs. This is reflected in the change in the activity of enzymes. First of all, it concerns enzymes involved in the regulation of energy metabolism. These changes could cause disorders of oxidative-reducing processes in muscle tissue of the crayfish [67, 68]. 
The alkaline phosphatase is involved in the hydrolysis of phosphates and membrane transport, and is also used as an indicator of stress in biological systems. The change in the activity of this enzyme indicates certain disorders in cells membrane [69]. It is known that in ecotoxicological studies, alkaline phosphatase is used as a bioindicator for heavy metals [70]. The change in the activity of the enzyme during the influence of lead may indicate a decrease in the functional activity of the specified organ in the case of intoxication with this heavy metal, since it has a cumulative effect. Its effect could cause a decrease in the synthesis of the molecules of this enzyme. In addition, it could cause a violation of the structure and permeability of cellular organelles and cause acidosis.

The effect of nickel and manganese caused the opposite picture of the change in the activity of this enzyme. This could cause increased phosphorylation processes to ensure normal growth and proliferation of cells under conditions of their intoxication.

Changes in the activity of enzymes were also reflected in the overall protein content. Thus, under the influence of lead, manganese and nickel ions, $(\mathrm{p}<0.05)$ the total protein content decreased by $16.3 \%, 32.7 \%$ and $44.1 \%$ respectively. A significant decrease in the total protein content due to the activity of the investigated nickel concentration may be due to a significant damage of the organs by this heavy metal. In general, the action of toxicants could cause the catabolism of proteins, which in the process of decay into amino acids were used for energy needs in the processes of detoxification of tissues. It should also be noted that the significant use of protein in energy metabolism could cause waterborne of crayfish tissues. This is a kind of result of exhaustion due to the negative effects of toxic compounds on tissue homeostasis.

\section{Conclusions}

The emergence of marbled crayfish in the reservoirs of the Dnipropetrovsk region can signal the possible acclimatization and further distribution of the species through the territory of Ukraine. The rapid spread of this species in water bodies in Europe is due to the wide possibilities of parthenogenetic marmorkrebs to adaptations, even in reservoirs with a tense toxicological condition.

Ions of heavy metals in model concentrations $\left(\mathrm{Ni}^{2+}-0.04 \mathrm{mg} / \mathrm{L}(4 \mathrm{MAC}), \mathrm{Pb}^{2+}-0.15 \mathrm{mg} / \mathrm{L}\right.$ (1.5 MAC), $\mathrm{Mn}^{2+}-0.02 \mathrm{mg} / \mathrm{L}(2 \mathrm{MAC})$ ) caused death of hydrobionts and influenced the crustacean mass indexes. On the 21 st day of the experiment, $26.7 \%$ of the crayfish died in the lead experiment, and $13.3 \%$ in the experiment with manganese. The largest mortality of crustaceans was observed in the experiment with nickel and reached $60.0 \%$.

The obtained results of the research indicate significant changes in the individual biochemical parameters of marbled crayfish due to the influence of heavy metals. Changes in these parameters may indicate a rapid biochemical response of the investigated species of crustaceans to the toxic effects of heavy metals. Changes in these indicators may be further used in the study of it in natural reservoirs in order to predict qualitative and quantitative changes within Zaporizhzhya (Dnipro) reservoir, where it is gradually naturalizing.

\section{Conflict of Interest}

The authors declare that there is no conflict of interest. 


\section{References}

[1] K.K. Holoborodko et al., The problem of assessing the viability of invasive species in the conditions of the steppe zone of Ukraine, Visnyk of Dnipropetrovsk University Biology, Ecology. 24(2) (2016) 466-472.

[2] O. Marenkov et al., Efect of zinc and cadmium ions on histostructure of antennal glands of marbled crayfsh Procambarus fallax (Hagen, 1870) f. virginalis (Decapoda), Acta Biologica Universitatis Daugavpiliensis. 17(2) (2017): 219-224.

[3] Yu.S.Voronkova et al., The problem of the study of oxidative stress in biological research. Bioindication and Ecology Questions, 21(1-2) (2016) 222-234. (in Ukrainian).

[4] Y.S. Voronkova, O.M. Marenkov, K.K. Holoborodko, Liver antioxidant system of the Prussian carp and pumpkinseed as response to the environmental change, Ukrainian Journal of Ecology. 8(1) (2018) 749-754.

[5] T. Ananieva, Indexes of lipid metabolism in fish from the Zaporizke Reservoir, International Letters of Natural Sciences. 64 (2017) 10-16.

[6] O. Fedonenko, T. Sharamok, T. Ananieva, Biochemical parameters of blood in fish from Zaporozhian Reservoir, International Letters of Natural Sciences. 51 (2016) 43-50.

[7] R.A. Novitsky, M.O. Son, The first records of Marmorkrebs [Procambarus fallax (Hagen, 1870) f. virginalis] (Crustacea, Decapoda, Cambaridae) in Ukraine, Ecologia Montenegrina. 5 (2016) 44-46.

[8] O. Marenkov et al., Paremeters of the histological adaptation of marmorkrebs Procambarus fallax f. virginalis (Decapoda, Cambaridae) to Zinc and Cadmium ions pollution, World scientific news. 90 (2017) 189-202.

[9] G. Kotovska et al., East European crayfish stocks at risk: arrival of non-indigenous crayfish species, Knowl. Manag. Aquat. Ecosyst. 417 (2016) 37.

[10] F. Lyko, The Marbled Crayfish (Decapoda: Cambaridae) represents an independent new species, Zootaxa. 4363(4) (2017) 544-552.

[11] P. Martin et al., The enigmatic Marmorkrebs (marbled crayfish) is the parthenogenetic form of Procambarus fallax (Hagen, 1870), Contributions to Zoology. 79 (2010) 107-118.

[12] P. Martin et al., The first record of the parthenogenetic Marmorkrebs (Decapoda, Astacida, Cambaridae) in the wild in Saxony (Germany) raises the question of its actual threat to European freshwater ecosystems, Aquatic Invasions. 5 (2010) 397-403.

[13] Z. Faulkes, Marmorkrebs (Procambarus fallax f. virginalis) are the most popular crayfish in the North American pet trade, Knowledge and Management of Aquatic Ecosystems. 416 (2015) 20-35.

[14] H.H. Hobbs, The crayfishes of Florida, Biological Science Series. 3(2) (1942) 1-179.

[15] C.A. Taylor et al., Conservation status of crayfishes of the United States and Canada, Fisheries. 21(4) (1996) 25-38.

[16] C. Chucholl, M. Pfeiffer, First evidence for an established Marmorkrebs (Decapoda, Astacida, Cambaridae) population in Southwestern Germany, in syntopic occurrence with Orconectes limosus (Rafinesque, 1817), Aquatic Invasions. 5(4) (2010) 405-412.

[17] S. Peay, D.M. Holdich, J. Brickland, Risk assessments of non-indigenous crayfish in Great Britain, Freshwater Crayfish. 17 (2010) 109-122.

[18] F.N. Marzano et al., The first record of the marbled crayfish adds further threats to fresh waters in Italy, Aquatic Invasions. 4(2) (2009) 401-404.

[19] B. Lipták et al., Expansion of the marbled crayfish in Slovakia: Beginning of an invasion in the Danube catchment? Journal of Limnology. 75(2) (2016) 305-312.

[20] P. Bohman et al., The first Marmorkrebs (Decapoda: Astacida: Cambaridae) in Scandinavia, BioInvasions Records. 2(3) (2013) 227-232. 
[21] J. Patoka, L. Kalous, O. Kopecký, Imports of ornamental crayfish: the first decade from the Czech Republic's perspective. Knowledge and Management of Aquatic Ecosystems. 416 (2015) 4-13.

[22] T. Kawai, M. Takahata, The biology of freshwater crayfish, Hokkaido University Press, Sapporo, 2010.

[23] G. Scholtz et al., Parthenogenesis in an outsider crayfish, Nature. 421(6925) (2003) 769-873.

[24] F. Alwes, G. Scholtz, Stages and other aspects of the embryology of the parthenogenetic Marmorkrebs (Decapoda, Reptantia, Astacida), Development Genes and Evolution. 216(4) (2006) 169-184.

[25] Z. Faulkes, The spread of the parthenogenetic marbled crayfish, Marmorkrebs (Procambarus sp.), in the North American pet trade, Aquatic Invasions. 5(4) (2010) 447-450.

[26] P. Martin, S. Thonagel, G. Scholtz, The parthenogenetic Marmorkrebs (Malacostraca: Decapoda: Cambaridae) is a triploid organism, Journal of Zoological Systematics and Evolutionary Research. 54(1) (2016) 13-21.

[27] A. S. Jimenez, Z. Faulkes, Establishment and care of a laboratory colony of parthenogenetic marbled crayfish, Marmorkrebs, Invertebrate Rearing. 1 (2010) 10-18.

[28] G. Vogt, Suitability of the clonal marbled crayfish for biogerontological research: A review and perspective, with remarks on some further crustaceans, Biogerontology. 11(6) (2010) 643-669.

[29] G. Vogt et al., The marbled crayfish as a paradigm for saltational speciation by autopolyploidy and parthenogenesis in animals, Biology Open. 4(11) (2015) 1583-1594.

[30] Physician ethics and human rights: the provisions for the use of animals in biomedical research, Exp. Clin. Physiol. Biochem. 22(2) (2003) 108-109. (in Ukrainian).

[31] V.S. Asatiani, New methods of biochemical photometry, Science, Moscow, USSR, 1965. (in Russian)

[32] Methods of biochemical research (lipid and energy metabolism), Leningrad University, Leningrad, USSR, 1982. (in Russian)

[33] J.H. Lowry et al., Protein measurement with the Folin phenol reagent, J. Biol. Chem. 193(1) (1951) 265-275.

[34] O. Kori-Siakpere, R.B. Ikomi, M.G. Ogbe, Variations in acid phosphatase and alkaline phosphatase activities in the plasma of the african catfish: Clarias gariepinus exposed to sublethal concentrations of potassium permanganate, Astan J. Exp. Boil. Sci. 1(1) (2010) $170-174$.

[35] T.C. Diamantino et al., Lactate dehydrogenase activity - an effective parameter in aquatic toxicity tests, Chemosphere. 45 (2001) 530-560.

[36] R. Varadarajan, Biochemical effects of different phenolic compounds on Oreochromis Mosambicus (Peters), Ph.D. thesis, Cochin University of Science and Technology, 2010.

[37] A. Cohen, G. Nugegova, M.M. Gagnon, Metabolic responses of fish following exposure to two different oil spills remediation techniques, Ecotoxicol. Environ. Saf. 48(3) (2001) 306310.

[38] M. S. Zaki, M. Olfat, F. S. Shalaki, Phenol toxicity affecting hematological changes in cat fish (Clarius lazera), Life science journal. 8(2) (2011) 244-248.

[39] A. Alesander et al., Evaluation of changes in metabolic parameters and enzymes involved in metabolic pathways in Clarias botrachus after exposed to phenolic compounds, Asian Journal of Biomedical and Pharmacential Sciences. 3(21) (2013) 60-67.

[40] S. Agrahari, G. Krishna, Fate and toxicity of cadmium and lead accumulation in different tissues (gills, liver, kidney, brain) of a freshwater fish Channa punctatus, Journal of Ecophysiology and Occupational Health. 3(4) (2007) 151-155. 
[41] R.P. Yadav et al., Metabolic changes in fresh water fish Channa punctatus due to Stem bark Extract of Croton tiglium, J. Biol. Sci. 6(14) (2003) 1223-1228.

[42] P. Palanisamy et al., Activity levels of phosphatases of the air-breathing catfish Mystus cavasius exposed to electroplating industrial effluent chromium, Biology and Medicine. 4(2) (2012) 60-64.

[43] C. Bakde, A. N. Poddar, Effect of steel plant effluent on acid and alkaline phosphatases of gills, liver and gonads of Cyprinus carpio Linn, International Journal of Environmental Sciences. 1(6) (2011) 1305-1316.

[44] R. Thirumavalavan, Effect of copper on carbonydrate metabolism fresh water fish, Catla catla, Asian Journal of Science and Technology. 5 (2010) 095-099.

[45] H. Jiang et al., Response of Acid and alkaline phosphatase activities to copper exposure and recovery in freshwater fish Carassius auratus gibelio var, Life Science Journal. 9(3) (2012) $233-245$.

[46] G. Sreekala, S. Raghuprasad, G. Bela, Zutshi biochemical markers and histopathology of the target tissues of Labeo rohita reared in freshwater lakes of Bangalore, Karnataka, India, Journal of Research in Environmental Science and Toxicology. 2(2) (2013) 43-52.

[47] I. Valocky et al., Activity of alkaline phosphatase, acidic phosphatase and nonspecific esterase in the oviducts of puerperal ewes after exposure to polychlorinated biphenyls, Veterinarni Medicina. 52(5) (2007) 186-192.

[48] B. Jyothi, G. Narajan, Pesticide induced alterations of non-protein nitrogenous constituents in the serum of a freshwater catfish, Clarias batrachus (Linn.), Indian J. Exp. Biol. 38 (2000) $1058-1061$.

[49] A. S. Fatma, M. S. Gad, Environmental pollution-induced biochemical changes in tissues of tilapia zillii, Solea Vulgaris and mugil carpito from lake Qarun, Egypt. Global Veterenaria. 2(6) (2008) 327-336.

[50] A. Sachar, S. Raina, Effect of inorganic pollutant (nitrate) on biochemical parameters of the fish, Aspidoparia Morar, International Journal of Innovative Research in Science, Engineering and Technology. 3(5) (2014) 12568-12573.

[51] M. Banaee, Adverse effect of insecticides on various aspects of fish's biology and physiology, in: S. Soloneski, M. Larramendy (Eds.), Insecticides-Basic and Other Applications Book, Published by InTech, Chapter 6, 2012, pp. 101-126.

[52] M. Banaee, K. Ahmadi, Sub-lethal toxicity impacts of endosulfan on some biochemical parameters of the freshwater crayfish (Astacus leptodactylus), Research Journal of Environmental Sciences. 5(11) (2011) 827-835.

[53] F. Aziz et al., Effect of fluoride exposure on key enzymes activity of proteincarbohydrate metabolism in gills of fresh water fish tilapia mossambica, Keenjhar lake, Thatta, Sindh, Pakistan, Int. Res. J. Environment Sci. 2(8) (2013) 24-27.

[54] R.M. Ganeshwade, P.B. Rokade, S.R. Sonwane, Impact of dimethoate on protein content in the freshwater fish Puntius ticto (Ham), The Bioscan. 7(1) (2012) 153-155.

[55] H. Bhattacharya, L. Lun, R.D. Gomez, Biochemical effects to toxicity of CCl4 on rosy barbs (Puntius conchonius), J. Our Nat. 3 (2005) 10-25.

[56] K. M. Adamu, O. Kori-Siakpere, Effects of sublethal concentrations of tobacco (Nicotiana tobaccum) leafdust on some biochemical parameters of hybrid catfish (Clarias gariepinus and Heterobranchus bidorsalis), Brazilian Archives of Biology and Technology. 54(1) (2011) 183-196.

[57] S. B. Mushigeri, R. C. Kuri, Blood glucose and glycogen levels as indicators of stress in the freshwater, Journal of Ecotoxicology and Environmental Monitoring. 15 (2005) 1-5. 
[58] S. S. Vutukuru, Acute effects of hexavalent chromium on survival, oxygen consumption, hematological parameters and some biochemical profiles of the Indian major carp, Labeo rohita, Int. J. Environ. Res. Public Health. 2(3) (2005) 456-457.

[59] V. Rajamanickam, N. Muthuswamy, Effect of heavy metals induced toxicity on metabolic biomarkers in common carp (Cyprinus Carpio L.), Mj. Int. J. Sci. Tech. 2(1) (2008) 192-200.

[60] E.O. Oruc, N. Uner, Effects of 2, 4 Diamin on some parameters of protein and carbohydrate metabolisms in the serum, muscle and liver of Cyprinus carpio, Life Science Journal. 9(3) (2012) 267-272.

[61] A. Yadav et al., Fertilizer industry effluent induced biochemical changes in fresh water teleost, Channa striatus (Bloch), Bull. Environ. Contam. Toxicol. 79(6) (2007) 588-595.

[62] K. George et al., Biochemical changes in liver and muscle of the cichlid, Oreochromis mossambicus (Peters, 1852) exposed to sub-lethal concentration of mercuric chloride, Indian J. Fish. 59(2) (2012) 147-152.

[63] H. M. Neft, Use of biochemical measurement todetect pollutant-mediated damage to fish, ASTM. Spec Tech. Publ. 854 (1985) 155-183.

[64] J.A. Almeida et al., The use of the oxidative stress responses as biomarkers in Nile tilapia (Oreochromis niloticus) exposed to in vivo cadmium contamination, Environ Int. 27 (2002) 673-679.

[65] N. Indra, P.R. Karpagaganapathy, V. Meenakshi, Succinic dehydrogenase activity in tissues of male tree frog, Polypedates maculatus (Gray) exposed to median lethal dose of phosphamidon, Environment \& Ecology. 17(1) (1999) 14-17.

[66] T.G. More, R.A. Rajput, N.N. Bandela, Effect of heavy metal on enzyme succinic dehydrogenase of freshwater bivalve, Lamellidenus marginalis, Poll. Res. 24 (2005) 675-679.

[67] A.A. Ivanov et al., Physiological and biochemical adaptation of river crayfish (Astacus astacus) with a change in the mineralization of the aquatic environment, Izv TCAAU. 3 (2011) 120-128. (In Russian)

[68] N.N. Nemova, Mechanisms of biochemical adaptation in aquatic organisms, Ecological and Evolutionary Aspects. (2010) 198-214. (In Russian)

[69] R. Molina et al., Acid and alkaline phosphatase activities and pathological changes induced in Tilapia fish (Oreochromis sp.) exposed subchronically to microcystins from toxic cyanobacterial blooms under laboratory conditions, Toxicon. 46 ( 2005) 725-735.

[70] H. Nchumbeni et al., Effect of arsenic on the enzymes of the rohu carp, Labeo rohita (Hamilton, 1822), The Raffles Bull. of Zoology supplement. 14 (2007) 17-19. 